Pacific Journal of Mathematic 


\title{
SIMPLE PROOF OF A THEOREM OF P. KIRCHBERGER
}

\author{
Moshe Shim Rat
}

In their paper Rademacher and Schoenberg [2] give a simple proof of a theorem due to P. Kirchberger [1] on separation of sets in the Euclidean $n$-space by means of hyperplanes. Their proof utilizes Helly's theorem on convex sets and is one instance of several important applications of that theorem given in their paper.

The object of this note is to give a simple direct proof of Kirchberger's theorem. Our proof does not use Helly's theorem and is based on the well-known theorem of Carathéodory on convex sets (which is also utilized by Rademacher and Schoenberg in their derivation of Helly's theorem).

The statement and proof of the theorem follow.

Theorem of P. Kirchberger. Let $S$ and $T$ be two finite sets of points in the Euclidean $n$-space, $E^{n}$. If any $k+1$ points of $S$ may be separated from any $l+1$ points of $T$ by a hyperplane of $E^{n}(k+l \leq n)$, then $S$ may be separated from $T$ by a hyperplane of $E^{n}$.

Proof. We first prove our theorem under the (seemingly) stronger condition that the assumption of the theorem holds for any $k, l$ satisfying $k \leq n, l \leq n$, instead of $k+l \leq n$.

It is well-known that two compact convex sets in $E^{n}$ having no point in common may be separated by a hyperplane of $E^{n}$. The assertion of the theorem is therefore equivalent to the following: The convex hulls $H(S)$ and $H(T)$ of $S$ and $T$ respectively have no point in common. If this were not the case, any point of $H(S) \cap H(T)$ would, by Carathéodory's theorem, belong to two simplexes of dimensions not exceeding $n$ with vertices in $S, T$ respectively. But, according to our assumption, the vertices of the one simplex may be separated from those of the other by a hyperplane of $E^{n}$, and therefore their convex hulls may be similarly separated. The contradiction obtained proves the validity of our assertion.

Received September 22, 1953. This paper was given in a seminar on convex bodies conducted by Prof. A. Dvoretzky at the Hebrew University, Jerusalem.

Pacific J. Math. 5 (1955), 361-362 
Next we show that if there are two subsets of $S, T$ consisting of $k+1, l+1$ points resp. with $k \leq n, l \leq n$, which cannot be separated by a hyperplane, then there necessarily exist two subsets consisting of $k_{1}+1, l_{1}+1$ points resp. of $S, T$, with $k_{1}+l_{1} \leq n$, which also cannot be separated by a hyperplane.

Indeed let $A, B$ be two sets in $E^{n}$, consisting of $k+1, l+1$ points respectively $(k \leq n, l \leq n)$ which cannot be separated by a hyperplane. The set $H(A) \cap H(B)$ is non-void; let $P_{0}$ be one of its points and $\sigma^{k^{\prime}}, \tau^{l^{\prime}}$ two simplexes with vertices in $A$ and $B$ respectively containing $P_{0}$ in their (relative, that is, $k^{\prime}$-or $l^{\prime}$-dimensional $)$ interior. We denote by $E^{k^{\prime}}, F^{l}$ the "minimal flats" (linear manifolds of minimum dimension) containing $\sigma^{k^{\prime}}, \tau^{l^{\prime}}$ respectively. In case $k^{\rho}+l^{\rho}>n$, the flat $E^{k^{\prime}} n F^{l^{\prime}}$ is at least $l$-dimensional and so contains a ray issuing from $P_{0}$. If $P_{1}$ is the first point on that ray which does not belong to the (relative) interior of both $\sigma^{k^{\prime}}$ and $\tau^{l}$, then $P_{1}$ is an interior point of some faces (at least one of them proper) $\sigma^{k^{\prime \prime}}$ and $\tau^{l \prime \prime}$ of $\sigma^{k^{\prime}}$ and $\tau^{l}$ resp., where $k^{\prime \prime}+l^{\prime \prime}<k^{\prime}+l^{\ell}$. By repeating this process of reducing the dimension-sum we can ultimately make it smaller than or equal to $n$, which gives the required result.

This completes the proof of our theorem.

\section{REFERENCES}

1. P. Kirchberger, Über Tschebyscheffsche Annäherungsmethoden, Math. Ann., 57 (1903), 509-540.

2. H. Rademacher, I. J. Schoenberg, Helly's theorem on convex domains and Tchebycheff's approximation problem, Can. Journ. Math. 2 (1950), 245-256.

HE BREW UNIVERSITY

JER USALEM 


\section{PACIFIC JOURNAL OF MATHEMATICS}

\section{EDITORS}

\author{
H.L. ROYDEN \\ Stanford University \\ Stanford, California \\ E. HEWITT \\ University of Washington \\ Seattle 5, Washington
}

\author{
R. P. DILWORTH \\ California Institute of Technology \\ Pasadena 4, California \\ * Alfred Horn \\ University of California \\ Los Angeles 24, California
}

\section{ASSOCIATE EDITORS}

\section{H, BUSEMANN \\ HERBERT FEDERER}

MARSHALL HALL

\section{P.R. HALMOS \\ HEINZ HOPF}

ALFRED HORN

\author{
R.D. JAMES \\ BØRGE JESSEN \\ PAUL LÉVY
}

GEORGE PÓLYA

J.J. STOKER

KOSAKU YOSIDA

\section{SPONSORS}

UNIVERSITY OF BRITISH COLUMBIA

UNIVERSITY OF SOUTHERN CALIFORNIA

CALIFORNIA INSTITUTE OF TECHNOLOGY

UNIVERSITY OF CALIFORNIA, BER KELEY

STANFORD RESEARCH INSTITUTE

STANFORD UNIVERSITY

UNIVERSITY OF CALIFORNIA, DAVIS

UNIVERSITY OF. UTAH

UNIVERSITY OF CALIFORNIA, LOS ANGELES

WASHINGTON STATE COLLEGE

UNIVERSITY OF CALIFORNIA, SANTA BARBARA

UNIVERSITY OF WASHINGTON

MONTANA STATE UNIVERSITY

UNIVERSITY OF NEVADA

OREGON STATE COLLEGE

AMERICAN MATHEMATICAL SOCIETY

HUGHES AIRCRAFT COMPANY

UNIVERSITY OF OREGON

SHELL DEVELOPMENT COMPANY

\section{UNIVERSTTY OF SOUTHERN CALIFORNIA}

Mathematical papers intended for publication in the Pacific Journal of Mathematics should be typewritten (double spaced), and the author should keep a complete copy. Manuscripts may be sent to any of the editors. Manuscripts intended for the outgoing editors should be sent to their successors. All other communications to the editors should be addressed to the managing editor, Alfred Horn, at the University of California Los Angeles 24, California.

50 reprints of each article are furnished free of charge; additional copies may be obtained at cost in multiples of 50 .

The Pacific Journal of Mathematics is published quarterly, in March, June, September, and December. The price per volume (4 numbers) is $\$ 12.00$; single issues, $\$ 3.50$; back numbers (Volumes $1,2,3$ ) are available at $\$ 2.50$ per copy. Special price to individual faculty members of supporting institutions and to individual members of the American Mathematical Society: $\$ 4.00$ per volume; single issues, $\$ 1.25$.

Subscriptions, orders for back numbers, and changes of address should be sent to the publishers, University of California Press, Berkeley 4, California.

Printed at Ann Arbor, Michigan. Entered as second class matter at the Post Office, Berkeley, California.

* During the absence of E.G. Straus.

UNIVERSITY OF CALIFORNIA PRESS - BERKELEY AND LOS ANGELES 


\section{Pacific Journal of Mathematics}

\section{Vol. 5, No. $3 \quad$ November, 1955}

Nesmith Cornett Ankeny and S. Chowla, On the divisibility of the class number of quadratic fields ............................. 321

Cecil Edmund Burgess, Collections and sequences of continua in the plane ........................................ 325

Jane Smiley Cronin Scanlon, The Dirichlet problem for nonlinear elliptic equations....................................... 335

Arieh Dvoretzky, A converse of Helly's theorem on convex sets ......... 345

Branko Grünbaum, On a theorem of L. A. Santaló................ 351

Moshe Shimrat, Simple proof of a theorem of P. Kirchberger .......... 361

Michael Oser Rabin, A note on Helly's theorem . ................... 363

Robert E. Edwards, On factor functions . . ................... 367

Robert E. Edwards, On certain algebras of measures ............... 379

Harley M. Flanders, Methods in affine connection theory.............. 391

Alfred Huber, The reflection principle for polyharmonic functions ........ 433

Geoffrey Stuart Stephen Ludford, Generalised Riemann invariants ....... 441

Ralph Gordon Selfridge, Generalized Walsh transforms............. 451 